\title{
ЩОДО ОКРЕМИХ ПИТАНЬ ІНВЕСТИЦІЙНО-ІННОВАЦІЙНОГО СКЛАДНИКА ВІТЧИЗНЯНОЇ ЕКОНОМІКИ В УМОВАХ СТАЛОГО РОЗВИТКУ УКРАЇНИ
}

Сошников А. 0 .

Стаття присвячена аналізу основних проблем, що стоять на заваді розвитку національної економіки як інвестиційно-інноваційної, а також дослідженню шляхів можливого вирішення цих проблем.

Побудова української економіки за інвестиційно-інноваційним сценарієм можлива тільки через поєднання зусиль держави (виступає регулятором), бізнес-середовища (залучає інвестиціі) та науки (продукує технологіі).

Для наближення української економіки до інноваційної запропоновано такі заходи, як: пільгові умови кредитування через збільшення строків кредитування, через часткову компенсацію відсоткової ставки комерційних банків; популяризація окремих галузей економіки чи проєктів через активізацію представників дипломатичних представництв; створення дієвої платформи для залучення інвестицій через створення спеціалізованої державної установи, що буде забезпечувати консультування зацікавлених осіб, надавати організаційну та методичну підтримку, а також буде інформаційним банком стартапів.

Ключові слова: інвестиції, інноваційна економіка, сталий розвиток, інноваційний розвиток.

Статья посвящена анализу основных проблем, стоящих на пути развития национальной экономики как инвестиционно-инновационной, а также исследованию путей возможного решения данных проблем.

Построение украинской экономики по инвестиционно-инновационному сценарию возможно только через объединение усилий государства (выступает регулятором), бизнес-среды (привлекает инвестиции) и науки (производит технологии).

Для приближения украинской экономики к инновационной предложены такие меры, как: льготные условия кре дитования через увеличение сроков кредитования, через частичную компенсацию процентной ставки коммерческих банков; популяризация отдельных отраслей экономики или проектов через активизацию представителей дипломатических представительств; создание действенной платформы для привлечения инвестиций через создание специализированного государственного учреждения, которое будет обеспечивать консультирование заинтересованных лиц, оказывать организационную и методическую поддержку, а также будет информационным банком стартапов.

Ключевые слова: инвестиции, инновационная экономика, устойчивое развитие, инновационное развитие.

The article is devoted to the analysis of the main problems that hinder the development of the national economy, as investment and innovation, as well as to explore ways of possible solution of these problems.

The structure of the national economy continues to remain commodity, although the state is constantly announcing a course

Сошников А. О., 2019 on its innovative development, which can only be ensured by attracting investment in high-tech and concrete goods and services.

Building the Ukrainian economy under the investment-innovation scenario is possible only through the combination of efforts of the state (acting as regulator), business environment (attracting investment) and science (producing technology).

Local infrastructure (transport, high-speed Internet coverage, etc.) plays an important role in attracting foreign investment to innovative projects.

The proposal to create a State Investment Bank, which could be an analogue of the European Investment Bank, may be a good idea. Consideration should also be given to transferring preferential lending to innovative projects to existing state-owned banks, for example: Savings Bank JSC, as it already has experience in granting preferential loans to specific sectors and priority programs (youth mortgage lending or energy supply).

Consideration should also be given to the creation of a government agency that will raise investment funds to create and market innovative products; advising both business and academic institutions or individual researchers; presentation of scientific achievements and startups at various international venues.

More active involvement of the diplomatic missions of Ukraine with foreign countries and representatives of the diplomatic missions of foreign countries in Ukraine to promote certain sectors of the economy and innovative projects is argued.

Key words: investments, innovative economy, sustainable development, innovative development.

Постановка проблеми та їі актуальність. Структура національної економіки продовжує залишатися сировинною, хоча держава постійно проголошує курс на їі інноваційний розвиток, який може бути забезпечений тільки шляхом залучення інвестицій у високотехнологічні та конкурентоспроможні товари та послуги.

Аналіз останніх досліджень і публікацій. Останніми роками як учені-економісти, так і вчені-правники приділяють значну увагу інноваційному розвитку вітчизняної економіки, зокрема і через залучення іноземних інвестицій, серед них - М. Денисенко, І. Бродюк, Д. Сташенюк, М. Стегней, К. Глухарев, В. Сподіна, В. Башилова, І. Лобас, Н. Мамонтова та інші. Незважаючи на ґрунтовні дослідження цих та інших дослідників, $\epsilon$ нагальна необхідність у додаткових дослідженнях зазначеного питання, оскільки залучення інвестицій, у тому числі іноземних, у новітні технології продовжує бути індикатором розвитку та досягнень «оновленої» економічної політики держави.

Метою цієї статті $\epsilon$ аналіз основних проблем, що стоять на заваді розвитку національної економіки як інвестиційно-інноваційної, а також шляхів можливого вирішення цих проблем.

Виклад основного матеріалу. Побудова української економіки за інвестиційно-інноваційним сцена- 
рієм можлива тільки через поєднання зусиль держави (виступає регулятором), бізнес-середовища (залучає інвестиції) та науки (продукує технології).

За даними Всесвітнього економічного форуму, у Звіті про глобальну конкурентоспроможність 20172018 років Україна посіла 81 місце серед 137 досліджуваних держав, піднявшись на чотири позиції. За компонентами показника, який характеризує ефективність ринків, - ключового фактора на стадії інвестиційного зростання (індустріалізації) - Україна посідає 101 місце за ефективністю товарних ринків серед 137 держав, 120 - за ефективністю фінансових ринків і 86 - за ефективністю ринку праці. Готовність до адаптації технологій та інновацій оцінена на рівні 81 місця. При цьому за показником «Ринкові інституції» наша держава посідає 118 місце, а за розвитком бізнесу - 90. Серед факторів, важливих для розвитку промисловості, сприятливими є хіба що розмір доступного ринку (за ємністю ринку Україна посідає 47 місце) та освіта (наша держава посідає 35 місце). Незважаючи на велику кількість учених та інженерів, а також частку людей, які мають вищу освіту, Україна має посередній рейтинг за показником «Інновації» та низькі значення показників «Взаємозв' язки університетів з промисловістю у сфері досліджень і розробок», «Технологічна готовність». Найбільш проблемним залишається показник «Іноземні інвестиції та трансфер технологій».

Відповідно до індексу інноваційного розвитку, представленого агентством Bloomberg у 2018 році, Україна перебуває на 53 місці серед 60 досліджуваних держав. При цьому наша держава виявилася найгіршою за продуктивністю праці (60 місце), що свідчить про низький рівень застосовуваних технологій та виробництва товарів з низькою доданою вартістю, потрапила до трійки аутсайдерів за технологічними можливостями (58 місце) та посідає 54 місце за рівнем витрат на дослідження та розробки у валовому внутрішньому продукті. Водночас вона зберігає високе 28 місце за ефективністю вищої освіти та 35 місце за патентною активністю, тобто має потенціал до розвитку [1]. Відповідні аналітичні дані свідчать про незадовільний рівень розвитку галузей вітчизняної економіки, нездатність вітчизняних товарів бути конкурентними на світовому ринку та невідповідність їх викликам «інноваційної революції», а також про відсутність повноцінної дієвої та ефективної стратегії держави в цьому напрямі. Інвестиційний процес в Україні не виконує функцію сприяння оновленню виробничої бази на інноваційній основі, результатом реалізації якої мала б стати структурна перебудова національної економіки у напрямі формування виробництв 3 довгостроковими інноваційними конкурентними перевагами [2, с. 104].

На постіндустріальній стадії розвитку інвестиції мають нести не лише матеріально-речове, а й інтелектуальне та інноваційне «навантаження», тобто всі інвестиції мають бути інноваційно орієнтованими [3].

Необхідно констатувати, що Кабінетом Міністрів України було схвалено досить прогресивну Стратегію розвитку сфери інноваційної діяльності на період до 2030 року. Так, відповідно до Стратегії розвитку сфери інноваційної діяльності на період до 2030 року основними проблемами функціонування національної інноваційної системи є:
- на етапі створення новацій: недостатність фінансування, зокрема державного; відсутність необхідної інформації про ринкові перспективи запропонованої ідеї та знань і консультативного супроводу проходження проєкту від ідеї до етапу комерціалізації; недостатнє використання науковцями та малим і середнім бізнесом можливостей щодо участі у міжнародних програмах; відсутність налагоджених комунікацій між науковцями і представниками бізнесу, які заінтересовані в розвитку інновацій як до потреб бізнесу в інноваціях, так i даних про нові та вдосконалені технологічні рішення, які можуть бути використані у виробництві; відсутність достовірного прогнозування тенденцій та досліджень впливу інструментів державного регулювання інноваційного розвитку економіки;

- на еmani mрансферу новацій: недостатність фінансування через непередбачуваність комерційних результатів новацій; розбіжності щодо врегулювання відносин у сфері інтелектуальної власності; обмеженість фінансових та матеріальних ресурсів для створення інноваційної інфраструктури; нестача фахівців у сфері менеджменту інноваційної діяльності, управління інтелектуальною власністю, маркетингу, правової охорони, фінансових консультантів, експертів 3 трансферу технологій і бізнес-планування; відсутність інформації про інформаційних партнерів; відсутність закріпленого у законодавстві механізму передачі технологій, створених або придбаних за бюджетні кошти, за кордон; низький рівень заінтересованості закладів вищої освіти у провадженні інноваційної діяльності; обмеження на внески у вигляді нематеріальних активів для закладів вищої освіти та наукових установ під час формування статутного капіталу, створення юридичних осіб для впровадження науково-технічних результатів;

- на етапі впровадження новації шляхом створення спеціалізованого малого інноваційного підприємства - cmapmany: обтяжливе регулювання, зокрема ускладнений доступ до ринку праці іноземців та надмірно ускладнений процес ліквідації підприємства, що $\epsilon$ вкрай актуальним для стартапів, оскільки інноваційна діяльність $€$ високоризикованим видом бізнесу і частина стартапів виявляється неуспішною; високий рівень податків (насамперед на оплату праці та прибуток підприємств); недостатність необхідних знань і навичок для ведення підприємницької діяльності; великі за обсягом витрати для новоутвореного підприємства на оренду приміщень та обладнання, оплату сторонніх послуг (насамперед бухгалтерських); відсутність або обмежена ефективність інноваційної інфраструктури, яка має сприяти розвитку інноваційного підприємництва;

- на еmani впровадження новацій на вже наявному підприємстві, виходу на серійне виробництво: недостатній рівень заінтересованості суб'єктів господарювання у впровадженні результатів вітчизняних наукових досліджень і науково-технічних (експериментальних) розробок, які потребують додаткового часового та фінансового ресурсу для їх повноцінного застосування; недостатня поінформованість про можливості малих і середніх підприємств у сфері використання новацій, високі транзакційні витрати на пошук та доступ до баз даних, відсутність ефективних каналів передачі інформації щодо попиту підприємств до сектору науки та освіти; недостатність незалежної оцінки технологічного рівня науково-технічної (експеримен- 
тальної) розробки та можливості технічно їі реалізувати; недостатність у інноваторів (осіб, які створюють нові або удосконалюють наявні конкурентоздатні технології, продукти (продукцію) та/або послуги) презентаційних навичок, вмінь оцінки обсягів коштів, які вони можуть отримати від підприємства, що несе основні ризики під час впровадження новації; відсутність «спільної мови» представників бізнесу та науки; низький рівень обізнаності інноваторів у сфері правової охорони та захисту інтелектуальної власності [1].

Необхідно погодитись, що динамічний поступ в інноваційній сфері можна досягти тільки шляхом створення сприятливого інноваційно-інвестиційного середовища та ефективного механізму державно-приватного партнерства [2, с. 193].

Сучасна вітчизняна економічна політика має базуватися на інноваціях, що забезпечить можливість ефективного розвитку економічних відносин та прискорення інтеграції економіки держави у світове господарство з високим рівнем конкуренції, де екстенсивна модель господарювання уже вичерпала свої можливості [4].

М. Денисенко, І. Бродюк, Д. Сташенюк розглядають інвестиції та інновації як базу для нарощення економічного потенціалу будь-якої країни і основу для формування конкурентоспроможності національної економіки [5].

Необхідно погодитись, що «інновації-інвестиції» це єдина взаємопов'язана система, адже саме інновації забезпечують високий якісний рівень інвестицій [6].

За даними інноваційного табло $€ С$, Україна має значні нереалізовані можливості в інноваційному розвитку. Сучасний стан інноваційної діяльності $€$ наслідком відсутності стратегічного бачення та послідовної державної політики щодо переведення України на інноваційний шлях розвитку, формування національної інноваційної екосистеми (сукупності інституцій, відносин, а також різних видів ресурсів, задіяних у процесі створення та застосування наукових знань та технологій, що забезпечують розвиток інноваційної діяльності), яка забезпечувала б його реалізацію і підвищувала розвиток інноваційної культури в державі, використовуючи, крім фінансових, інші механізми розвитку інноваційної діяльності. Попри наявність окремих елементів, відсутня цілісна національна інноваційна система, призначення якої - створення інноваційних продуктів (процесів) та їх швидке виведення на ринок (впровадження). Наявні в Україні структурні елементи національної інноваційної екосистеми та нормативно-правове поле їх функціонування не вибудовані в єдину конструкцію, тому результати діяльності цих елементів поодинокі та не мають синергетичного ефекту, який має полягати у збільшенні ефективності національного виробництва товарів (послуг) та посилення їх конкурентоспроможності за рахунок широкомасштабного впровадження результатів наукових досліджень і науково-технічних (експериментальних) розробок [2].

Серед основних бар'єрів для розвитку інновацій в Україні -недосконалість інституцій, зокрема політичного, регуляторного та бізнес-середовища; слабко розвинута інфраструктура, у тому числі інноваційна, оскільки залишаються на низькому рівні показники валового нагромадження капіталу у відсотках до валового внутрішнього продукту, показники екологічної стійкості, доступності та якісної роботи електронного
Уряду (використання інформаційних та комунікаційних технологій у поєднанні з організаційними змінами та застосуванням нових навичок у державному управлінні для впровадження державних послуг та демократичних процесів) [2].

В. Сподіна, В. Башилова підкреслюють, що відсутність коштів на реалізацію перспективних проєктів, прогалини законодавства у сфері інноваційної діяльності та її результатів, відсутність податкових знижок і стимулів для впровадження новітніх технологій у серійне виробництво, недостатнє інформаційне забезпечення ринку новітніх технологій - все це стримує розвиток інноваційної діяльності в країні [7, с. 82]. Для підтримки інноваційно-інвестиційного розвитку підприємств державі необхідно впроваджувати більш ефективну антимонопольну політику, пільгову політику оподаткування підприємств, що працюють в інноваційній сфері, підтримувати пільгове кредитування підприємСтв [7, с. 83].

Н. Мамонтова пропонує такі шляхи вирішення зазначених проблем:

- активізувати подання заявок для фінансування інвестиційних та інноваційних пропозицій у структурні фонди та грантові програми ЄC;

- вжити заходів щодо стимулювання інвестиційної діяльності в малому підприємництві (пільгові кредити, спеціальні гранти тощо);

- стимулювати ринковий попит на інновації і використання концепції «лідируючих» ринків, що передбачає підтримку ринків, найбільш сприйнятливих до нововведень;

- прискорити темпи створення та оновлення інноваційної інфраструктури;

- вжити заходів фіскального стимулювання капіталомістких інвестиційних проєктів;

- створити Державний інвестиційний банк з метою пільгового стимулювання інвестиційних проєктів на пріоритетних напрямах (із жорстким контролем за його діяльністю) $[8$, с. 123].

І. Лобас наголошує, що не повною мірою впроваджуються в практику такі інструменти державної підтримки інноваційно-інвестиційної діяльності, як: здешевлення довгострокових кредитів з частковою компенсацією відсоткової ставки комерційних банків за рахунок бюджетних коштів; спрямування частини коштів, отриманих від приватизації державного майна, на фінансування інноваційної діяльності підприємств, що мають стратегічне значення для економіки та безпеки держави; механізм державно-приватного партнерства. Тому доцільно продовжити стимулювання створення спеціалізованих інноваційних банків, а також фондів довгострокового кредитування функціонуючих комерційних банків шляхом встановлення відповідних пільг з оподаткування коштів, що інвестуються, з метою здійснення технологічних зрушень, внесення змін до порядку розподілу коштів від податку на додану вартість [9].

Досить слушною $є$ пропозиція створення саме Державного інвестиційного банку, що може стати аналогом Європейського інвестиційного банку. Також можна розглянути передачу функції надання пільгового кредитування для інноваційних проєктів уже наявним державним банкам, наприклад АТ «Ощадбанк», оскільки він уже має досвід надання пільгових 
кредитів окремим галузям та пріоритетним програмам (зокрема, молодіжного іпотечного кредитування або енергозабезпечення).

Необхідно також розглянути створення державної установи, що буде займатися залученням інвестиційних коштів для створення та реалізації інноваційних продуктів; наданням консультацій як представникам бізнес-середовища, так і науковим закладам чи окремим дослідникам; презентацією наукових досягнень та стартапів на різних міжнародних майданчиках.

Доцільно також більш активно залучати дипломатичні представництва України за кордоном та представників дипломатичних представництв іноземних держав в Україні для популяризації окремих галузей економіки, інноваційних проєктів.

Також не можна применшувати роль місцевої інфраструктури на етапі залучення іноземних інвестицій в інноваційні проєкти (наприклад, транспортне сполучення, покриття високошвидкісним Інтернетом тощо).

Висновки. Наближення української економіки до інноваційної продовжує залишатися в фокусі державі, але впевнено можна стверджувати, що на практиці відсутні дієві практичні кроки у цьому напрямі.

Такими кроками можуть бути:

- пільгові умови кредитування через збільшення строків кредитування, через часткову компенсацію відсоткової ставки комерційних банків;

- популяризація окремих галузей економіки чи проєктів через активізацію представників дипломатичних представництв;

- створення дієвої платформи для залучення інвестицій через створення спеціалізованої державної установи, що буде забезпечувати консультування зацікавлених осіб, надавати організаційну та методичну підтримку, а також буде інформаційним банком стартапів.

Відповідні проблеми потребують подальших пошуків вирішення, що вже у середньостроковій перспективі дасть змогу збільшити залучення іноземних інвестицій в інноваційну економіку України.

\section{Література}

1. Про схвалення Стратегії розвитку сфери інноваційної діяльності на період до 2030 року : Розпорядження Кабінету Міністрів України від 10.07.2019 року № 526-р. Офіційний вісник України. 2019. № 57. Ст. 1983.

2. Інноваційна Україна 2020 : національна доповідь / за заг. ред. В.М. Гейця та ін. ; НАН України. Київ, 2015. 336 с.

3. Сподіна В.О. Інновації та інвестиції: сутність і взаємозв'язок. Ефективна економіка. 2013. № 12. URL: http: / / www.economy. nayka.com.ua/?op=1\&z=2640.

4. Стегней M.І. Інвестиційно-інноваційні домінанти сталого розвитку територіальних одиниць. URL: http://www. economyandsociety. in.ua/journal/1_ukr/09.pdf.

5. Денисенко М.П., Бродюк І.В., Сташенюк Д.Г. Основні положення формування інвестиційно-інноваційної стратегії підприємства. Інвестиції: практика та досвід. 2016. № 22/2016. URL: http://www. investplan.com.ua/ pdf/22_2016/6.pdf.

6. Глухарев К.А. Инновации и инвестиции: сущность, взаимодействие и роль в воспроизводственном процесce. URL: https://cyberleninka.ru/article/n/innovatsii-iinvestitsii-suschnost-vzaimodeystvie-i-rol-v-vosproizvodstvennom-protsesse.

7. Сподіна В.О., Башилова В.П. Інноваційно-інвестиційні процеси в національній економіці та підприємництві. Сучасні проблеми економіки та підприємництво. 2014. № 13. С. 78-86.

8. Мамонтова Н. Тенденції фінансування інвестиційної та інноваційної діяльності. Актуальні проблеми економіки. 2015. № 12(174). С. 118-124.

9. Лобас І.В. Особливості інноваційно-інвестиційної політики України. URL: http://academy.gov.ua/ej/ej14/ txts/Lobas.pdf.

Сошников А. О., кандидат юридичних наук, провідний юрист сектору проблем реалізації господарського законодавства Iнституту економіко-правових досліджень Національної академії наук України, член Координаційної ради молодих юристів України при міністерстві юстиції України 